paleoenvironmental implications. J. Afr. Earth Sci., 2016, 123, 123-144.

37. Brinkhuis, H., Late Eocene to Early Oligocene dinoflagellate cysts from the Priabonian type-area (northeast Italy): biostratigraphy and paleoenvironmental interpretation. Palaeogeogr., Palaeoclimatol., Palaeoecol., 1994, 107, 121-163.

38. Dybkjaer, K., Morphological and abundance variations in Homotryblium-cyst assemblages related to depositional environments; uppermost Oligocene-Lower Miocene, Jylland, Denmark. Palaeogeogr., Palaeoclimatol., Palaeoecol., 2004, 206, 41-58.

39. Dale, B. and Fjellsa, A., Dinoflagellate cysts as paleoproductivity indicators: state of the art, potential, and limits. In Carbon Cycling in the Glacial Ocean: Constraints on the Ocean's Role in Global Change (eds Zahn, R. et al.), Springer-Verlag, Berlin, 1994, pp. 521-537.

40. Edwards, L. E., New semiquantitative (paleo) temperature estimates using dinoflagellate cysts, an example from the North Atlantic Ocean. In Neogene and Quaternary Dinoflagellate Cysts and Acritarchs (eds Head, M. J. and Wrenn, J. H.), American Association of Stratigraphic Palynologists Foundation, Dallas, Texas, USA, 1992, pp. 69-87.

41. Wall, D., Dale, B., Lohmann, G. P. and Smith, W. K., The environmental and climatic distribution of dinoflagellate cysts in modern marine sediments from regions in the North and South Atlantic Oceans and adjacent areas. Mar. Micropaleontol., 1977, 2, 121200.

42. Edwards, L. E. and Andrle, V. A. S., Distribution of selected dinoflagellate cysts in modern marine sediments. In Neogene and Quaternary Dinoflagellate Cysts and Acritarchs (eds Head, M. J. and Wrenn, J. H.), American Association of Stratigraphic Palynologists Foundation, Texas, USA, 1992, pp. 259-288.

43. Udeze, C. U. and Oboh-Ikuenobe, F. E., Neogene paleoceanographic and paleoclimatic events inferred from palynological data: Cape Basin off South Africa, ODP Leg 175. Palaeogeogr., Palaeoclimatol., Palaeoecol., 2005, 219, 199-223.

44. Ogg, J. G., Ogg, G. and Gradstein, F. M., A Concise Geologic Time Scale, Elsevier, 2016, pp. 1-240; ISBN: 9780444637710.

45. Martini, E., Standard Tertiary and Quaternary calcareous nannoplankton zonation. In Proceedings of the Second Planktonic Conference Roma 1970 (ed. Farinacci, A.), Edizioni Tecnoscienza, Rome, 1971, vol. 2, pp. 739-785.

ACKNOWLEDGEMENTS. We thank the Director, Birbal Sahni Institute of Palaeosciences, Lucknow for providing necessary facilities and permission (BSIP/RDCC/Publication no. 95/2017-18) for this publication. P.V. also thank Dr M. R. Rao for his help and constant encouragement.

Received 12 April 2018; revised accepted 6 March 2019

doi: $10.18520 / \mathrm{cs} / \mathrm{v} 116 / \mathrm{i} 9 / 1571-1580$

\section{Water retention and transmission characteristics of containerized growing media amended with differential proportions of compressed coir bricks}

\author{
Simrat Singh ${ }^{1, *}$, S. S. Kukal ${ }^{2}$ and R. K. Dubey ${ }^{1}$ \\ ${ }^{1}$ Department of Floriculture and Landscaping, and \\ ${ }^{2}$ Department of Soil Science, Punjab Agricultural University, \\ Ludhiana 141 004, India
}

The hydraulic characteristics of growing media play an equally important role as do the architectural properties in the production of ornamental potted plants. The reuse of biological agri-wastes, amended with cocopeat and soil, has potential for ameliorating the hydro-physical environment in growing media substrates, affecting air-water relations. A study was undertaken to evaluate the water retention and transmission characteristics of four biological wastes as base media (farmyard manure (FYM), leaf mould (LM), rice husk ash (RHA) and composted sewage sludge (CSS)) amended with different proportions of soil : coir mixture $(0: 75,25: 50,50: 25,75: 0)$ respectively. These media mixtures were filled in 3.51 pots. Utilization of coir $<50 \%$ (per cent of pot volume) as an amendment in FYM and CSS-based media mixtures improved hydraulic characteristics of pot-growing media. The use of RHA amended with soil : coir was not suitable as a growing medium due to higher relative evaporation rate and higher rate of infiltration. Water retention in terms of maximum water-holding capacity and available water increased with coir addition, the increase being enormous with $75 \%$ coir. Infiltration rate of water in the media improved with addition of coir (0-50\%), showing a steep increase $\left(4.25-8.10 \mathrm{~cm} \mathrm{~min}^{-1}\right)$ at highest $(75 \%)$ proportion of coir. Drainage rate was highest in FYM and LMbased media mixtures.

Keywords: Coir bricks, hydraulic characteristics, infiltration rate, pot media, water retention.

CONTAINERIZED ornamental plants are not only confined to private homes, but also aesthetically placed in mass multiplexes due to scarcity of spaces for beautification. Production of sustainable ${ }^{1}$, environment-friendly substrates $^{2}$, also referred to as growing media, has been utilized as an amendment for improving physio-chemical characteristics of media contained in finite-volume pots. However, research on pot-media hydraulics is still in its infancy, which is of vital importance to ornamental potted plant industry worldwide. The hydraulic characteristics responsible for air-water relations have been

*For correspondence. (e-mail: simratflori@pau.edu) 
discussed by researchers in different growing media substrates (pig manure ${ }^{3}$, peat ${ }^{4}$ and cocopeat + perlite $^{5}$, cocopeat + vermiculite + farm yard manure $($ FYM $))^{6}$. Production of quality ornamental, containerized plants ${ }^{7}$, including container trees ${ }^{8}$ depends on the growing media mixture that is likely to affect the irrigation scheduling. Ability of growing media to not only retain water, but also simultaneously maintain proper aeration status is indispensable for healthy functioning of the rooting system ${ }^{9}$ and quality production of plants in a limited volume of $\operatorname{pots}^{10}$. There is greater tendency for increased competition among roots in the rhizosphere (root zone) for water, air and space due to finite volume of the containers ${ }^{11}$. In addition, the applied water in finite soil medium leads to formation of a perched water table at the lower end of the pot due to restricted drainage. Thus, the lower layers of the soil medium in the pot may become near-saturated, leading to aeration stress for the roots, thus hindering water and nutrient uptake. On the other hand, the surface layers may become deficit in moisture leading to decreased water and nutrient availability to the plants ${ }^{12}$. The ability of the growing media to make a healthy balance between water content and gaseous exchange is critical for improving the keeping quality of ornamental plants.

The present-day containerized ornamentals are desired to be light-weight for their easy mobility and display apart from being water- and air-retentive ${ }^{13}$. Thus, it becomes pertinent to formulate moisture-conserving growing media mixture instead of soil alone for filling in the containers. This requires evaluation of different growing media components for water retention and transmission characteristics. The organic wastes, viz. composted FYM, leaf mould (LM), municipal composted sewage sludge (CSS) and rice husk ash (RHA), being rich in nutrients and also light-weight can be used as base media. However, these organic wastes, if used as a whole, may lead to high salinity ${ }^{14}$, acidity or toxicity of certain elements apart from being less water-conductive ${ }^{15,16}$. This necessitates the mixing of organic wastes with suitable amendments like coir (by-product of coconut industry), also used by several researchers in container studies ${ }^{17-19}$. The washed coir, light in weight with low shrinkage, low bulk density and slow biodegradation (due to high lignin and cellulose content $)^{20}$ with longer decomposition time can be an ideal amendment for media mixtures. It can be effectively recycled and has acceptable $\mathrm{pH}(5.2-6.8)^{21}$.

The hydraulic properties of container-growing media mixtures are vital to ornamental potted plant growers, to safeguard precious natural resource, water and reduce associated costs involved in repeated irrigations. The hydraulic characteristics of media mixtures such as water retention (water-holding capacity (WHC), availability of water) and transmission characteristics (infiltration rate, saturated hydraulic conductivity, evaporation and drainage) of growing media affect the plant-water relations, more so in limited-volume containers. The measure of infiltration of water into the pot media is an important indicator, for optimizing irrigation and drainage to improve the availability of water for plants and sustain their turgidity. The addition of amendments to organic wastes for neutralizing the toxic chemical effects, may alter water retention and transmission characteristics, depending upon the proportion of the amendment used. Thus, an attempt has been made to optimize the proportion (volume basis) of coir as an amendment for ameliorating water retention and transmission characteristics of growing media.

The objective of the present study was to evaluate differentially amended biological wastes with coir with respect to the variation in hydraulic (water retention and water transmission) properties of media mixtures.

The experiment was conducted at the Punjab Agricultural University (PAU) Landscape Nursery, Ludhiana. The site is located between $29^{\circ} 30-32^{\circ} 32^{\prime} \mathrm{N}$ and $73^{\circ} 55^{\prime}-$ $76^{\circ} 50^{\prime} \mathrm{E}$ at an altitude of $247 \mathrm{~m}$ amsl. The climate of the region is semi-arid with average annual rainfall of $650 \mathrm{~mm}$. Majority of the rainfall $(80 \%)$ occurs during a short span of two and half months (July-September). The maximum and minimum temperatures during the duration of the experiment were $39.9^{\circ} \mathrm{C}$ (August) and $5.9^{\circ} \mathrm{C}$ (December) respectively. The media mixtures comprised of four biological wastes, viz. FYM, LM, RHA and CSS as base media. These were amended with soil: coir mixture in four different proportions. The media mixtures were filled in earthern pots (3.5 l volume) with uniform packing. FYM comprised of cow and buffalo dung decomposed in pits for 12-18 months mixed with wheat straw used as bedding in animal sheds. CSS is semi-solid material left after fermentation and drying of urban domestic sewage. It was procured from municipal sewage treatment plant. RHA comprises of ash obtained after burning of rice husk as fuel in milling industry, and was procured from a local rice mill. LM is compost produced by fungal breakdown of pruned shrubs and tree leaves after complete decomposition in soil pits.

The treatments comprised of four biological wastes (FYM, LM, RHA and CSS) as base media amended with four different proportions of soil:coir in the ratio $0: 75$, $25: 50,50: 25,75: 0$ on per cent volume basis. The 3.51 volume pots were then filled with 16 combinations of base media ( $25 \%$ each on volume basis) amended with coir : soil $(0: 75,25: 50,50: 25,75: 0)$. The growing media combination treatments are as follows: FYM-based media (4) - T1 [FYM : coir: soil $(25: 0: 75)]$, T2 [FYM: coir : soil $(25: 25: 50)]$, T3 [FYM : coir : soil $(25: 50: 25)]$, T4 [FYM : coir : soil (25:75:0)]; LM-based media (4)T5 [LM : coir : soil $(25: 0: 75)]$, T6 [LM : coir : soil $(25: 25$ : 50)], T7 [LM : coir : soil $(25: 50: 25)]$, T8 [LM: coir : soil $(25: 75: 0)$ ]; RHA-based media (4) - T9 [RHA : coir : soil $(25: 0: 75)], \quad$ T10 [RHA: coir: soil $(25: 25: 50)]$, T11 [RHA : coir: soil $(25: 50: 25)], \quad$ T12 [RHA: coir: soil 
(25:75:0)]; CSS-based media (4) - T13 [CSS : coir : soil $(25: 0: 75)], \quad$ T14 [CSS: coir: soil $(25: 25: 50)], \quad$ T15 [CSS : coir : soil (25:50:25)] T16 [CSS: coir:soil (25: $75: 0)]$. The treatments were replicated four times and pots were kept in the open to ensure uniform light conditions.

The compressed coir bricks ( $5 \mathrm{~kg}$ ) were wrapped in gunny bags and kept overnight in a water-filled container for saturation. After $24 \mathrm{~h}$, the saturated coir bricks were thoroughly tapped with a wooden rod to ensure homogenous mixture of coir fibers. The wet coir fibre was allowed to dry under shade for $24 \mathrm{~h}$, ensuring drainage of excess water containing salts of sodium and chlorine. The mixtures of base media and soil + coir in different proportions were filled in earthen containers of 3.51 volume, measuring $24 \mathrm{~cm}$ in diameter and $17.5 \mathrm{~cm}$ in depth. The containers were filled with different media mixtures in small lots, while tapping each lot 10 times with a pointed wooden rod to ensure uniform packing. A head space of $2.4 \mathrm{~cm}$ above the media mixture was maintained for applying water. The pots were saturated with water immediately after packing so as to ensure settling down of media mixtures. The experiment was undertaken with pot-filled biological waste media, without plant(s), in order to characterize the potting media with respect to variation in hydraulic characteristics.

The water transmission characteristics, viz. infiltration rate, drainage, evaporation and saturated hydraulic conductivity were determined in situ. The infiltration rate of water in different media mixtures was recorded at $5 \mathrm{~min}$ intervals till a constant infiltration rate was achieved in each container. For this, each container was fixed with a collar of similar diameter (as the top of the container), maintaining a constant head $(10 \mathrm{~cm})$ of water above the surface of the media mixtures. The constant head was maintained using Mariotte arrangement and drop in the water level in the Mariotte bottle was recorded as the amount of water infiltered during the prefixed time interval. The ratio of the water infiltered and the time interval was expressed as infiltration rate $\left(\mathrm{cm} \mathrm{min}^{-1}\right)$.

The drainage rate of the media mixtures was quantified by recording the volume of water collected $(\mathrm{ml})$ in drainage plates kept at the bottom of 1 litre container. A fixed amount $(50 \mathrm{ml})$ of water was applied to each container. The containers were kept undisturbed for $1 \mathrm{~h}$ and water was allowed to drain out completely from the container. The water collected in the drainage plates was measured in a measuring cylinder and ratio of water drained to that $(50 \mathrm{ml})$ applied was expressed as per cent drainage.

The evaporation rate from the surface of the media mixtures was recorded periodically. The containers after saturation with water were placed in the open, ensuring full interception of sunlight. The containers were weighed after the drainage of water ceased after $24 \mathrm{~h}$ interval and loss in weight of the container was expressed as evaporation rate $\left(\mathrm{mm} \mathrm{day}^{-1}\right)$.
The saturated hydraulic conductivity was measured in situ in each container (5-10 cm depth) using Guelph permeameter. A hole $(1 \mathrm{~cm}$ diameter $)$ was made at 5$10 \mathrm{~cm}$ depth in the medium. The Guelph permeameter filled with water to its full capacity $(550 \mathrm{~mm})$ was kept over a piece of cloth placed over the surface of the hole to avoid blockage in the exit hole. The rate at which water infiltrated into the media was recorded at periodic intervals, till it became constant. The rate of constant water flow was expressed as saturated hydraulic conductivity $\left(\mathrm{cm} \mathrm{min}^{-1}\right)$.

The available water was determined as the difference in moisture content at 0.3 and 15 bar soil matric suction, as obtained from the pressure plate apparatus.

The maximum WHC was measured using Keen's box, $5 \mathrm{~cm}$ in diameter and perforated at the bottom. It was filled with media mixtures with continuous tapping from a height of $2.5 \mathrm{~cm}$ to ensure uniform packing and was kept in a water bath for $24 \mathrm{~h}$. The ratio of difference in the saturated and dry weights of the mixture to its oven dry weight was expressed as maximum WHC.

The bulk density $\left(D_{\mathrm{b}} ; \mathrm{mg} \mathrm{m}^{-3}\right)$ was determined using the soil core method ${ }^{22}$. The particle density $\left(D_{\mathrm{p}} ; \mathrm{mg} \mathrm{m}^{-3}\right)$ was determined using pycnometer method. Total porosity was computed using the equation

$$
\% f=\left(1-D_{\mathrm{b}} / D_{\mathrm{p}}\right) \times 100
$$

where $f$ is the total porosity $(\%), D_{\mathrm{b}}$ and $D_{\mathrm{p}}$ are bulk density and particle density respectively $\left(\mathrm{mg} \mathrm{m}^{-3}\right)$.

The air-filled porosity $\left(f_{\mathrm{a}}\right)$ was determined at field capacity moisture content as follows

$$
f_{\mathrm{a}}=(f-\theta)
$$

where $f$ is the total porosity (\%) and $\theta$ is the volumetric moisture content at field capacity $(\%)$.

The experiment was laid out in a completely randomized block design (CRD) with four replications. The data were analysed using analysis of variance (ANOVA) to calculate least square difference (LSD) at the 5\% level of significance ${ }^{23}$.

The available water $\left(\mathrm{AW} ; \theta_{\mathrm{FC}}-\theta_{\mathrm{PWP}}\right)$ in different growing media mixtures increased with increasing proportion of coir where $\theta_{\mathrm{FC}}$ is the volumetric moisture content at field capacity and $\theta_{\mathrm{PWP}}$ is the volumetric water content at Permanent Wilting Point. The base medium with $75 \%$ coir had highest mean AW of $61.1 \%$ compared to $14.7 \%$ in medium without coir. AW increased with increasing proportions of coir. The increase in AW due to addition of $75 \%$ coir was higher in FYM and RHA (92$108 \%$ ) than in LM and SS (25-31\%) base media (Figure $1)$. The addition of coir in increasing proportions increased the total porosity in all the base media (77.4$80.9 \%$ ) at $75 \%$ coir (Table 1). Research findings suggest that the growing media with AW of $20-30 \%$ (ref. 24), 




Figure 1. Unavailable and available water expressed as percentage of container volume in different growing media mixtures.

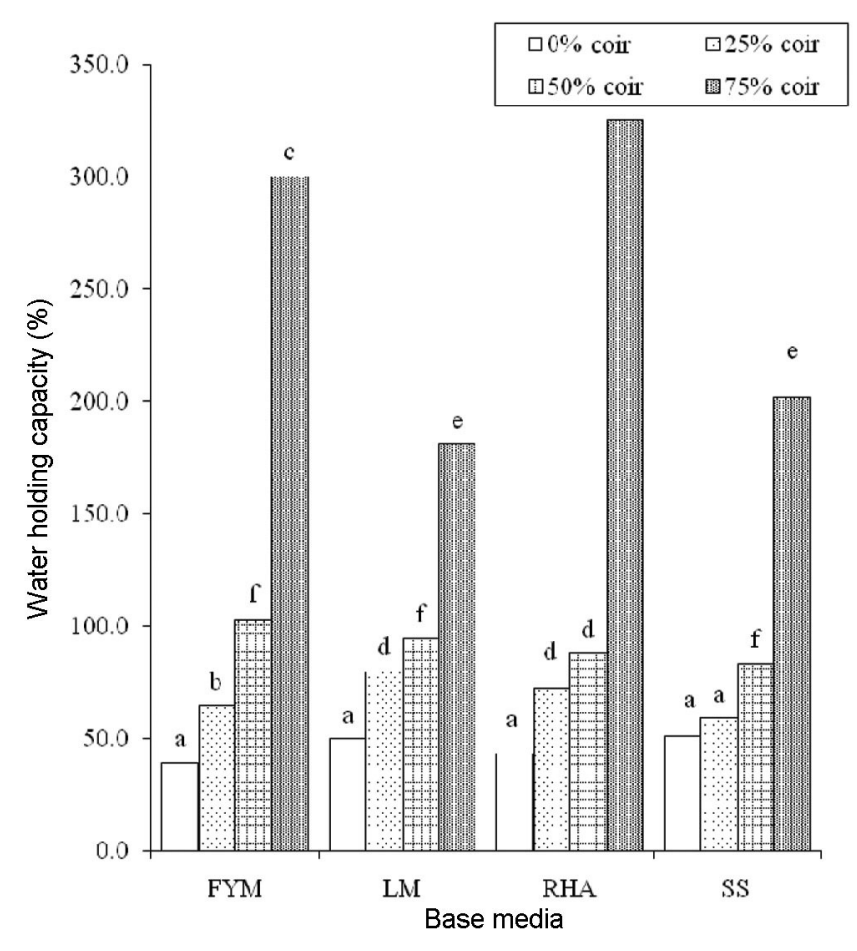

Figure 2. Water holding capacity (\%) of different growing media mixtures.

total porosity of $50-85 \%$ (ref. 25 ) of media volume are considered good for plant growth. Microstructural studies on coir pith showed the presence of several open cells with large empty cavities ${ }^{26}$, which can act as capillaries for absorption and retention of water and nutrients. Coir possesses a high degree of capillarity which helps in the redistribution of water after irrigation especially in the restricted pot volume. This increases the duration of water availability to the plants ${ }^{27}$. However, the LM and CSS media amended with coir could have resulted in largesized particle distribution, that increased the pore space and led to break of capillarity, decreasing the availability of water and increasing the drainage ${ }^{28}$.

WHC of different base media without coir was statistically similar (Figure 2). It ranged from $39.4 \%$ to $50.0 \%$ in different base media. Amending the base media with coir in different proportions (25-75\%) increased WHC. Addition of $75 \%$ coir in base media increased WHC of all the media mixtures, but the increase was higher in FYM $(300 \%)$ and RHA (325\%) compared to LM (181\%) and SS $(202 \%)$. This explains the higher AW in media mixtures comprising FYM and RHA amended with 75\% coir (Figure 1). In all the base media, WHC increased by 2-3 times with increase in proportion of coir from $50 \%$ to $75 \%$. Coir having honeycomb-like structure of the mesocarp tissue has high surface area, which leads to strong absorption of water ${ }^{29}$. Moreover, the coir consists of fibres derived from the mesocarp of coconut, that imbibe moisture (being hydrophilic in nature), forming a thin layer of water over the surface.

The basic infiltration rates (IRs) in the media mixtures comprising RHA and SS without coir were similar, whereas that comprising FYM had the lowest $(0.07 \mathrm{~cm}$ $\mathrm{min}^{-1}$ ) IR (Figure 3). Addition of coir increased IR in all the media mixtures. Addition of $25 \%$ coir increased IR by 2.0-6.57 times, the difference being lowest in SS and highest in RHA-based media mixtures. There was a drastic increase in IR in all the media mixtures with the addition of $75 \%$ coir, the increase being highest in RHAbased media mixtures. The infiltration being a surface phenomenon, is a function of water-conducting pores on the surface layer. RHA having higher saturated hydraulic conductivity $\left(K_{\text {sat }}\right)$ (Figure 4$)$, indicates higher total macro-porosity. This explains the higher infiltration of RHA-based media mixtures for all coir proportions. The rapid increase in $K_{\text {sat }}$ of media mixtures with $75 \%$ coir signifies the fact that flow of water through these media mixtures can be rapid or even turbulent ${ }^{30}$, as coir has been reported to show similarity in its hydraulic 
Table 1. Physical characteristics of different growing media mixtures

\begin{tabular}{lcccrc}
\hline $\begin{array}{l}\text { Base medium } \\
(25 \%, \mathrm{v} / \mathrm{v})\end{array}$ & $\begin{array}{c}\text { Soil }: \text { coir } \\
(\%, \mathrm{v} / \mathrm{v})\end{array}$ & $\begin{array}{c}\text { Bulk density } \\
\left(\mathrm{mg} \mathrm{m}^{-3}\right)\end{array}$ & $\begin{array}{c}\text { Total } \\
\text { porosity }(\%)\end{array}$ & $\begin{array}{c}\text { Maximum water } \\
\text { holding capacity }(\%)\end{array}$ & $\begin{array}{c}\text { Air-filled } \\
\text { porosity }(\%) *\end{array}$ \\
\hline FYM & $75: 0$ & $1.20 \pm 0.02$ & $48.7 \pm 2.04$ & $39.4 \pm 1.97$ & $25.1 \pm 1.05$ \\
& $50: 25$ & $0.99 \pm 0.03$ & $52.4 \pm 4.01$ & $64.5 \pm 3.13$ & $20.5 \pm 1.36$ \\
& $25: 50$ & $0.75 \pm 0.09$ & $62.5 \pm 5.20$ & $103.0 \pm 4.73$ & $23.9 \pm 1.57$ \\
& $0: 75$ & $0.31 \pm 0.04$ & $80.1 \pm 5.51$ & $300.0 \pm 10.8$ & $33.6 \pm 1.97$ \\
LM & $75: 0$ & $1.14 \pm 0.03$ & $51.4 \pm 4.65$ & $49.9 \pm 3.46$ & $23.0 \pm 1.73$ \\
& $50: 25$ & $0.82 \pm 0.02$ & $59.8 \pm 5.86$ & $79.7 \pm 3.86$ & $35.3 \pm 1.66$ \\
& $25: 50$ & $0.77 \pm 0.05$ & $61.1 \pm 3.75$ & $94.3 \pm 5.01$ & $24.8 \pm 1.52$ \\
& $0: 75$ & $0.43 \pm 0.03$ & $78.8 \pm 4.42$ & $181.1 \pm 12.5$ & $39.9 \pm 1.85$ \\
RHA & $75: 0$ & $1.21 \pm 0.04$ & $52.9 \pm 3.55$ & $43.3 \pm 3.10$ & $26.7 \pm 0.65$ \\
& $50: 25$ & $0.94 \pm 0.06$ & $60.8 \pm 3.52$ & $72.5 \pm 4.44$ & $26.7 \pm 1.20$ \\
& $25: 50$ & $0.87 \pm 0.03$ & $62.1 \pm 3.58$ & $87.7 \pm 6.05$ & $24.0 \pm 1.38$ \\
SS & $0: 75$ & $0.32 \pm 0.02$ & $80.9 \pm 4.60$ & $325.0 \pm 19.4$ & $29.0 \pm 2.37$ \\
& $75: 0$ & $1.18 \pm 0.03$ & $48.7 \pm 2.89$ & $50.8 \pm 2.56$ & $18.7 \pm 0.84$ \\
& $50: 25$ & $1.13 \pm 0.05$ & $51.9 \pm 3.62$ & $59.0 \pm 2.91$ & $18.6 \pm 1.12$ \\
& $25: 50$ & $0.87 \pm 0.03$ & $59.5 \pm 4.23$ & $83.1 \pm 5.22$ & $23.4 \pm 0.88$ \\
\hline
\end{tabular}

*Air-filled porosity calculated at field capacity. FYM, Farmyard manure; LM, Leaf mould; RHA, Rice husk ash; SS, Sewage sludge.
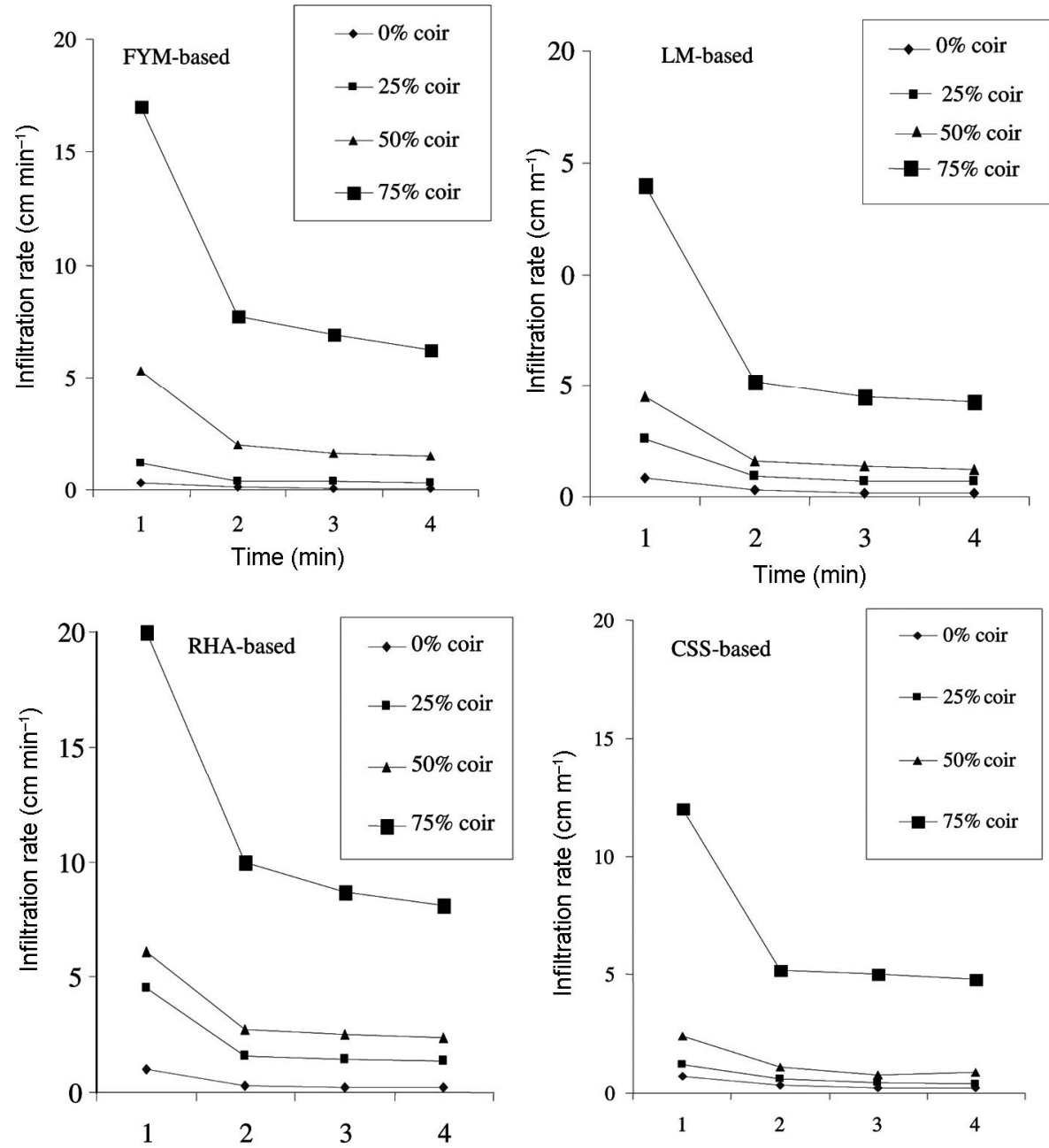

Figure 3. Periodic infiltration rate $\left(\mathrm{cm} \mathrm{m}^{-1}\right)$ in different growing media mixtures. 


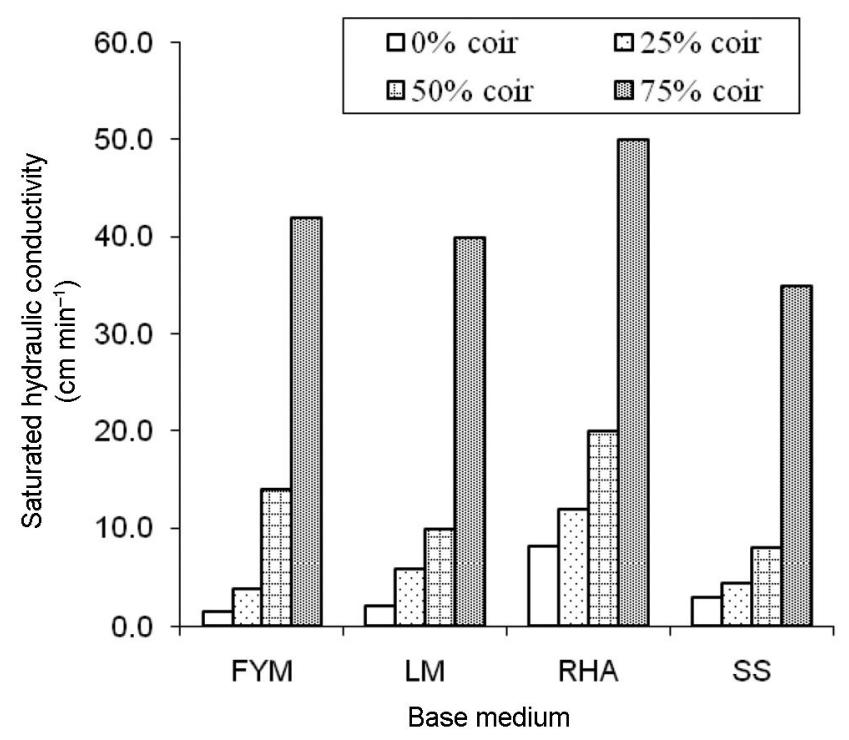

Figure 4. Saturated hydraulic conductivity $\left(\mathrm{cm} \mathrm{m}^{-1}\right)$ of different growing media mixtures.

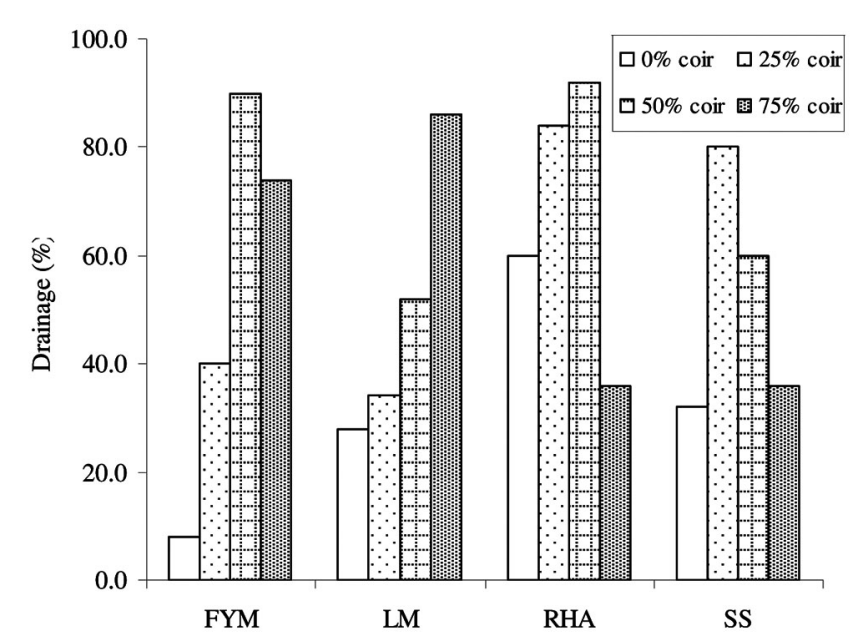

Figure 5. Extent of drainage (\%) during the first 5 min of irrigation in different growing media.

properties with peat exhibiting non-Darcian rate of flow of water ${ }^{31}$. This necessitates the use of micro-irrigation methods in irrigation scheduling for potted ornamentals containing base media with higher macro-porosity to safeguard against nutrient leaching and facilitate effective wetting of root zone.

The amount of water drained through media mixtures during the first five minutes of irrigation, in general, increases with the addition of coir (Figure 5). However, in FYM and RHA, the amount of water drained increases till $50 \%$ of coir addition, and it decreases thereafter. In LM, the water drained is highest in the media mixture containing $75 \%$ coir. LM containing decomposed leaf residue did not form a stable aggregate with soil and coir in pot media due to its loose and friable structure. This results in higher macro-porosity, leading to higher drai- nage of water. The reduction of drainage with higher amounts of coir could be attributed to the greater tendency of coir at higher proportions to absorb water due to its increased surface area. It is interesting to note that the rate of drainage is contrary to the observations recorded in periodic IR (Figure 3) at higher proportions of coir, where IR was highest with $75 \%$ coir. Similar findings were reported by $\mathrm{Hillel}^{32}$, where an inference was made that 'coir had the lowest easily available water and the highest hardly available water content'.

The addition of coir in all the base media increased the relative evaporation rate till $120 \mathrm{~h}$, the increase being more prominent in LM (Figure 6). In case of RHA amended with different levels of coir, the relative evaporation rate decreased sharply irrespective of the coir proportion till $120 \mathrm{~h}$. The increasing amount of coir increased initial relative evaporation rate more prominently in RHA than in the other base media. The higher rate of relative evaporation in RHA among all the base media could be due to its higher water supplying capacity, as is evident from WHC of RHA (Table 1). RHA, being dark and finer in texture compared to the other base media, absorbs solar radiation, becomes relatively more warm compared to the other base media and forms a loose fine layer at the surface which dries up immediately. The water molecules travel through this layer in vapour form, the vapour flow being drastically slow compared to liquid flow. This results in a sharp decline in relative evaporation rate. In case of FYM and LM base media, the stage 1 of evaporation is distinct. This indicates that the water is being continuously supplied to the surface through capillarity in these base media.

Thus hydraulic properties play a significant role in irrigation scheduling, especially potted plants containing media substrates amended with coir. Based on the 

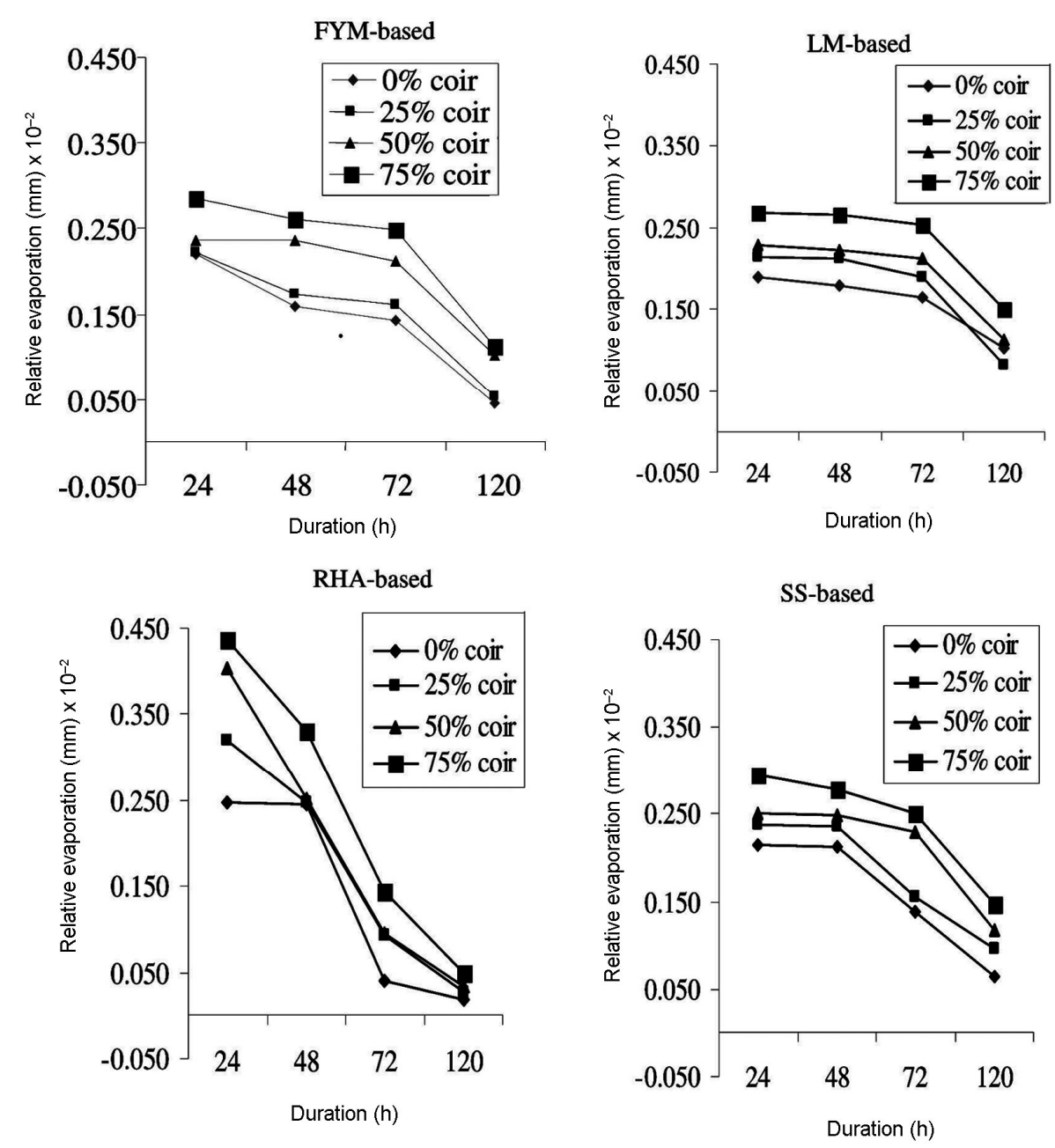

Figure 6. Relative evaporation rate $\left(\mathrm{mm} \mathrm{day}^{-1}\right)$ in different growing media.

research findings, it can be concluded that utilization of coir $<50 \%$ (per cent of pot volume) as an amendment in FYM and CSS-based media mixtures improved hydraulic characteristics of pot-growing media. The use of RHA amended with soil:coir is not suitable as growing medium due to higher relative evaporation rate and higher rate of infiltration. Future research needs to focus on the quantification of irrigation applied to potted plants taking into consideration the hydraulic properties, to optimize water requirement by regulating the frequency and quantity of irrigation.

1. Barrett, G. E., Alexander, P. D., Robinson, J. S. and Bragg, N. C., Achieving environmentally sustainable growing media for soilless plant cultivation systems - a review. Sci. Hortic., 2016, 212, 220 234.

2. Raviv, M. and Lieth, J. H., Soilless Culture, Elsevier, London, UK, 2008, p. 608.

3. Al Naddafa, O., Livieratos, I., Stamatakisa, A., Tsirogiannisb, I., Gizasb, G. and Savvasc, D., Hydraulic characteristics of composted pig manure, perlite, and mixtures of them, and their impact on cucumber grown on bags. Sci. Hortic., 2011, 129, 135-141.
4. Caron, J., Morel, P., Rivière, L. M. and Guillemain, G., Identifying appropriate methodology to diagnose aeration limitations with large peat and bark particles in growing media. Can. J. Soil Sci., 2010, 90, 481-494.

5. Ilahi, W. F. F. and Ahmad, D., A study on physical and hydraulic characteristics of cocopeat perlite mixture a growing media in containerized plant production. Sains Malays, 2017, 46(6), 975980 .

6. Thakur, T., Grewal, H. S. and Kukal, S. S., Impact of growing medium composition on morphological development of chrysanthemum (Chrysanthemum morifolium Ramat cv. Snowball). Curr. Sci., 2018, 115(6), 1198-1203.

7. Hall, C. R., Hodges, A. W. and Haydu, J. J., The economic impact of the green industry in the United States. HortTechnology, 2006, 16, 345-353.

8. Sax, M. S. and Scharenbroch, B. C., Assessing alternative organic amendments as horticultural substrates for growing trees in containers. J. Environ. Hortic., 2017, 35(2), 66-78.

9. Bar-Tal, A., The significance of root size for plant nutrition in intensive horticulture. In Mineral Nutrition of Crops: Fundamental Mechanisms and Implications (ed. Rengel, Z.), Haworth Press Inc, New York, USA, 1999, pp. 115-139.

10. Dubik, S. P., Krizek, D. T. and Stimart, D. P., Influence of root zone restriction on mineral element concentration, water potential, chlorophyll concentration and partitioning of assimilates in 
spreading euonymus (E. Kiautschovica Loes. 'Sieboldiana'. J. Plant Nutr., 1990, 13, 677-699.

11. Spomer, L. A., Cointainer soil-water relations: production, maintenance and transplanting. J. Arboricult., 1980, 6(12), 315-320.

12. Dressboll, D. B., Effect of growing media composition, compaction and periods of anoxia on the quality and keeping quality of potted roses (Rosa sp.). Sci. Hortic., 2010, 126, 56-63.

13. Dubey, R. K., Singh, S., Kukal, S. S. and Kalsi, H. S., Evaluation of different organic growing media for growth and flowering of petunia. Commun. Soil Sci. Plant Anal., 2013, 44, 1777-1785.

14. Awang, Y., Shaharom, S. A., Mohamad, R. B. and Selamat, A., Chemical and physical characteristics of coir-based media mixtures and their effects on the growth and development of Celosia cristata. Am. J. Agric. Biol. Sci., 2009, 4, 63-71.

15. Quinteroa, M. F., González-Murillo, C. A., Florez, V. J. and Guzmánb, J. M., Physical evaluation of four substrates for cut-rose crops. Acta Hortic., 2009, 843, 349-357.

16. Younis, A., Riaz, A., Waseem, M., Khan, A. and Nadeem, M., Production of quality crotons (Codiaeum variegatum) plants using different growing media. Am. Eur. J. Agric. Environ. Sci., 2010, 7, 232-237.

17. Erwan, M. R. I., Saud, H. M., Othman, R., Habib, S., Kausar, H. and Naher, L., Effect of oil plam frond compost amended coconut coir dust soilless growing media on growth and yield of cauliflower. Int. J. Agric. Biol., 2013, 15, 731-736.

18. Rubio, J. S., Pereira, W. E., Garcia-Sanchez, F., Murillo, L., García, A. L. and Martínez, V., Sweet pepper production in substrate in response to salinity, nutrient solution management and training system. Hortc. Bras., 2011, 29(3), 275-281.

19. Ayesha, R., Fatima, N., Ruqayya, M., Qureshi, K. M., Hafiz, I. A., Khan, K. S. and Kamal, A., Influence of different growth media on the fruit quality and reproductive growth parameters of strawberry (Fragaria ananassa). J. Med. Plants Res., 2011, 5(26), 6224-6232.

20. Londra, P., Paraskevopoulou, A. and Psychogiou, M., Hydrological behavior of peat- and coir-based substrates and their effect on begonia growth. Water, 2018, 10(6), 722.

21. Evans, M. R., Konduru, S. and Stamps, R. H., Source variation in physical and chemical properties of coconut coir dust. Hortic. Sci., 1996, 31, 965-967.

22. Blake, G. R. and Hartge, K. H., Bulk density. In Methods of Soil Analysis, Part I (ed. Klute, A.). ASA Monograph No. 9. Madison, WI, USA, 1986, pp. 363-376.

23. Steel, R. G. D. and Torrie, H., Principles and Procedures of Statistics, McGraw-Hill, New York, USA, 1960.

24. Vivek, K., Guerrero, F. M., Tansel, B. and Savabi, M. R., Hydrophysical characteristics of selected media used for containerized agricultural systems. Agric., Water Manage., 2010, 98, 314-320.

25. Starr, Z. W., Boyer, C. R. and Griffin, J. J., Eastern Redcedar (Juniperus virginiana) as a substrate component effects growth of three tree species. J. Environ. Hortic., 2012, 30(4), 189-194.

26. Fornes, F., Belda, R. M., Abad, M., Nougera, P., Puchades, R., Maquieira, A. and Noguera, V., The microstructure of coconut coir dusts for use as alternatives to peat in soilless growing media. Aust. J. Exp. Agric., 2003, 43, 1171-1179.

27. Carlile, W. R., Cattivello, C. and Zaccheo, P., Organic growing media: constituents and properties. Vadose Zone J., 2015, 14(6), $1-13$.

28. Abad, M., Fornes, F., Carrion, C. and Noguera, V., Physical properties of various coconut coir dusts compared to peat. Hortic. Sci., 2005, 40(7), 2138-2144.

29. Munroe, R., McGrath, D. and Henry, J., Increasing amounts of coir dust in substrates do not improve physical properties or growth of tree seedlings in a novel air-pruning propagation tray. J. Environ. Hortic., 2018, 36(3), 92-103.

30. Cresswell, G. C., Coir dust - a viable alternative to peat? In Proceedings of the Australian Potting Mix Manufacturers Conference, Sydney, 1992, pp. 1-5.
31. Beven, K. and Germann, P., Macropores and water flow in soils Water Resour. Res., 1982, 18(5), 1311-1325.

32. Hillel, D., L'eau et Ie sol, principes et processus physiques. Ed. Academia, Louvain-la-Neuve, Belgium, 1988, p. 288.

ACKNOWLEDGEMENTS. We thank the Head, Department of Soil Science and Estate Officer, Punjab Agricultural University (PAU), Ludhiana for providing the necessary facilities to carry out research at the PAU Landscape Nursery.

Received 29 December 2018; revised accepted 22 February 2019

\section{Avian mortalities from two wind farms at Kutch, Gujarat and Davangere, Karnataka, India}

\author{
Selvaraj Ramesh Kumar ${ }^{1, *}$, V. Anoop ${ }^{2}$, \\ P. R. Arun ${ }^{2}$, Rajah Jayapal ${ }^{2}$ and \\ A. Mohamed Samsoor Ali $^{2}$ \\ ${ }^{1}$ Bombay Natural History Society, Mumbai 400 001, India \\ ${ }^{2}$ Sálim Ali Centre for Ornithology and Natural History, \\ Coimbatore 641 108, India
}

Wind power is renewable and helps reduce greenhouse gas emission from the energy sector; however, it also has undesirable impacts on the environment. Studies from Europe and the USA report negative impact of wind farms on wildlife, especially on birds. India, the fourth largest producer of wind energy and also a mega biodiverse country has little information on this issue. Here, we report bird collisions from two wind farms: one at Kutch, Gujarat in western India and another from Davangere, Karnataka in southern India. A total of 47 bird carcasses belonging to at least 11 species in a period of three years were reported from Kutch and seven carcasses of at least three species in a period of one year were recorded at Davengere wind farm. The estimated annual bird mortality rate for Kutch was 0.478 birds/turbine and for Davengere it was 0.466 birds/turbine.

Keywords: Avian mortality, bird collisions, carcasses, wind turbines.

WIND power is one of the fastest growing renewable energy sectors in the world ${ }^{1}$. India is the fourth largest producer of wind energy with an installed capacity of

*For correspondence. (e-mail: ramesh.wild@gmail.com) 